\title{
FOUR RECENT INFLUENZA EPIDEMICS: AN EXPERIMENTAL STUDY
}

\author{
By FRANK L. HORSFALL, JR., RICHARD G. HAHN, AND E. R. RICKARD \\ (From the Laboratories of the International Health Division of The Rockefeller Foundation, \\ New York)
}

(Received for publication November 29, 1939)

The initial isolation of epidemic influenza virus by Smith, Andrewes, and Laidlaw (1) in 1933 has been followed by the isolation of a large number of strains of the virus in various parts of the world. One or more strains of epidemic influenza virus have been obtained from cases of epidemic influenza during each of the years from 1933 through 1937 (1-12). A total of more than 125 strains has been recorded. In the epidemics which have been reported previously the virus has been obtained from approximately 70 per cent of throat washings from persons who, during convalescence, showed an increase in neutralizing antibody titer against the virus. No great difficulty has been experienced in previous epidemics in determining the presence of the virus by the inoculation of ferrets.

During January 1939 a moderate increase in the usual incidence of acute infections of the respiratory tract was observed in many parts of the United States. In certain institutional populations this increase in acute respiratory infections assumed epidemic proportions, but in urban and suburban populations the morbidity rate was not high. Three localized epidemics in three separate institutions and one subepidemic in a suburban population have been studied intensively this year, and the results obtained will be presented in this paper. On the basis of the clinical and epidemiological findings in these institutional epidemics a diagnosis of epidemic influenza was made. It should be emphasized, however, that the clinical symptoms in the individual cases did not differ significantly from those observed in a series of cases of so-called sporadic "grippe" which had been studied prior to the occurrence of the epidemics. Had it not been for the high incidence of acute respiratory disease, a diagnosis of epidemic influenza on clinical grounds alone would not have been possible.

It is the purpose of this paper to report the results of attempts to isolate epidemic influenza virus by serial ferret passage from throat washings obtained from persons with epidemic influenza, as well as from throat washings obtained from persons with acute noninfluenzal respiratory diseases. The results of epidemic influenza virus neutralization tests on acute- and convalescentphase serum specimens from persons with epidemic influenza, persons with acute noninfluenzal respiratory disease, and persons who had contact with epidemic influenza will also be given. A clinical analysis and epidemiological observations on the four epidemics of influenza which were studied in 1939 will be presented.

\section{Clinical and epidemiological data}

The material upon which this paper is based was obtained from four epidemics which subsequently will be designated as Epidemics 1, 2, 3, and 4. Epidemic 1 occurred among the nursing staff of the Hospital of The Rockefeller Institute for Medical Research; Epidemic 2, at the New York State Vocational Institution, a reformatory for juvenile male delinquents at West Coxsackie, New York; Epidemic 3, among the suburban population at Yorktown Heights, New York, in a permanent observation area established for the study of upper respiratory disease by the International Health Division of The Rockefeller Foundation in cooperation with the Westchester County Department of Health; and Epidemic 4, at the Middletown State Homeopathic Hospital, a hospital for the insane at Middletown, New York.

Epidemic 1. Hospital of The Rockefeller Institute for Medical Research. Between January 7 and January 16, 1939, 6 members of the nursing staff developed an acute upper respiratory illness which was diagnosed clinically as epidemic influenza.

Epidemic 2. New York State Vocational Institution. In the period between January 11 and January 25, 1939,138 , or approximately 20 per cent, of the inmates of this institution were hospitalized with an acute febrile upper respiratory disease. Although this epidemic had a duration of 15 days, the onset of 75 per cent of the cases occurred during 3 days, January 16 , 17 , and 18. The epidemic was, therefore, quite explosive in character. Clinical and epidemiological investigations were undertaken by one of us (E. R. R.) 9 days after the beginning of the epidemic. Standard case histories 
were made out on 70 patients then in the hospital or admitted subsequently. Of these patients, 42 gave a history of sudden onset of symptoms and were able to state quite definitely the time of day when they became ill. In 13 cases the onset was gradual and consisted of illdefined symptoms which became more definite over a period of 1 to 7 days. Eleven patients gave a history of pre-existing head or chest " colds" which gradually grew worse or were suddenly aggravated by constitutional

TABLE I

Epidemic 2

Duration of fever $\left(98.6^{\circ} \mathrm{F}\right.$. plus) of patients hospitalized with epidemic influenza

\begin{tabular}{ccc}
\hline $\begin{array}{c}\text { Duration } \\
\text { of fever }\end{array}$ & $\begin{array}{c}\text { Number of } \\
\text { patients }\end{array}$ & $\begin{array}{c}\text { Per cent of } \\
\text { patients }\end{array}$ \\
\hline days & 2 & 1 \\
0 & 36 & 26 \\
1 & 45 & 33 \\
2 & 30 & 22 \\
3 & 14 & 10 \\
4 & 8 & 6 \\
5 & 3 & 2 \\
6 & 138 & 100 \\
\hline Total & &
\end{tabular}

TABLE II

Epidemic 2

Highest temperatures by days of patients hospitalized with epidemic influenza

\begin{tabular}{|c|c|c|c|c|c|c|}
\hline \multirow{2}{*}{ Temperatures, oral } & \multicolumn{6}{|c|}{ Days of illness } \\
\hline & 1 & 2 & 3 & 4 & 5 & 6 \\
\hline 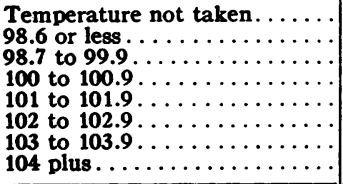 & $\begin{array}{r}17 \\
2 \\
28 \\
28 \\
31 \\
21 \\
9 \\
2\end{array}$ & \begin{tabular}{r|}
8 \\
41 \\
37 \\
22 \\
10 \\
10 \\
9 \\
1
\end{tabular} & $\begin{array}{r}3 \\
82 \\
25 \\
13 \\
8 \\
4 \\
3 \\
0\end{array}$ & $\begin{array}{r}48 \\
63 \\
14 \\
6 \\
5 \\
1 \\
1 \\
0\end{array}$ & \begin{tabular}{r|}
69 \\
54 \\
10 \\
3 \\
1 \\
1 \\
0 \\
0
\end{tabular} & $\begin{array}{r}93 \\
42 \\
0 \\
2 \\
0 \\
1 \\
0 \\
0 \\
\end{array}$ \\
\hline $\begin{array}{l}\text { Total number of patients } \ldots . . . \\
\text { Mean temperature of patients } \\
\text { with fever ( } 98.6 \text { plus) } \ldots \ldots \ldots\end{array}$ & $\begin{array}{c}138 \\
101.1\end{array}$ & $\begin{array}{c}138 \\
100.7\end{array}$ & $\begin{array}{c}138 \\
100.4\end{array}$ & $\begin{array}{c}138 \\
100.2\end{array}$ & $\begin{array}{c}138 \\
100.5\end{array}$ & $\begin{array}{c}138 \\
101.1\end{array}$ \\
\hline
\end{tabular}

symptoms. In Tables I and II data in regard to the duration of fever and the highest temperatures by days are summarized. In Figure 1 the relative frequency of symptoms among the group of 70 patients for whom standard history forms were made out is illustrated.

Dr. Anthony J. Flood, the physician for the institution, stated that during the epidemic there was a marked increase in the number of inmates reporting to the institution's dispensary for colds, sore throat, coughs, and other minor respiratory illnesses. In order to gain an idea as to the number of mild cases that may have occurred, 442 of the 604 inmates who had not been confined to the hospital were questioned in regard to history of upper respiratory disease during the period January 10 to 31 . This interrogation revealed that, in addition to the inmates who had been confined to the hospital, approximately 17 per cent gave histories of vague symptoms such as moderate chills, headache, sore throat, and cough, which were suggestive of unrecognized cases of influenza, and 7 per cent gave histories suggestive only of the "common cold." Questioning of 130 of the 154 officers and employees of the institution demonstrated attack rates of influenza, mild suggestive symptoms, and common colds very similar to those of the inmates.

Epidemic 3. Yorktown Heights. Since January 1938 there has been an observation area for the study of respiratory disease at Yorktown Heights, New York. In the first year of the study, in spite of frequent contacts with the population, no evidence was obtained of the existence of epidemic influenza in the area. In the same period the incidence of influenza was low in the surrounding region and in the country at large. Subsequent to September 1938 the families in the observation area were frequently and systematically interrogated. Eighteen cases of febrile upper respiratory disease clinically indistinguishable from epidemic influenza were seen during 1938. These occurred sporadically throughout the year and, with the exception of 3 cases occurring in a single family, had no apparent epidemiological connection. Almost concurrently with the appearance of Epidemic 2 and with an increase in acute febrile upper respiratory disease in Westchester County, there was an increase in febrile upper respiratory disease at the Yorktown Heights observation area as shown in Table III. The cases listed in this table were seen at least twice during the course of illness, and standard case history forms were made out on all. Although temperatures were always taken at the time of visit, the making of complete daily temperature records was impracticable. Elevation of temperature, however, was verified in 75 per cent of the total of 83 cases.

Clinically, this disease was similar to that observed in Epidemic 2. In 53 cases the onset was sudden; in 15 it was gradual after 1 or more days of indisposition; and in 13 , constitutional symptoms and fever followed pre-

TABLE III

Epidemic 3

Cases of epidemic influenza observed by weeks during the period January 12 to March 24, 1939

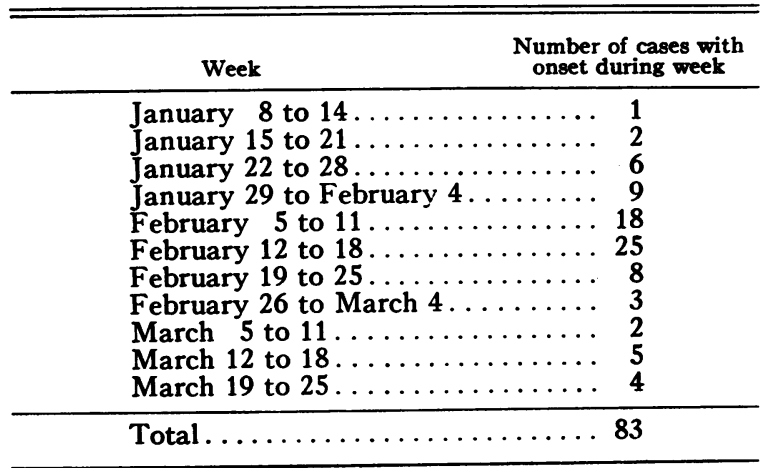




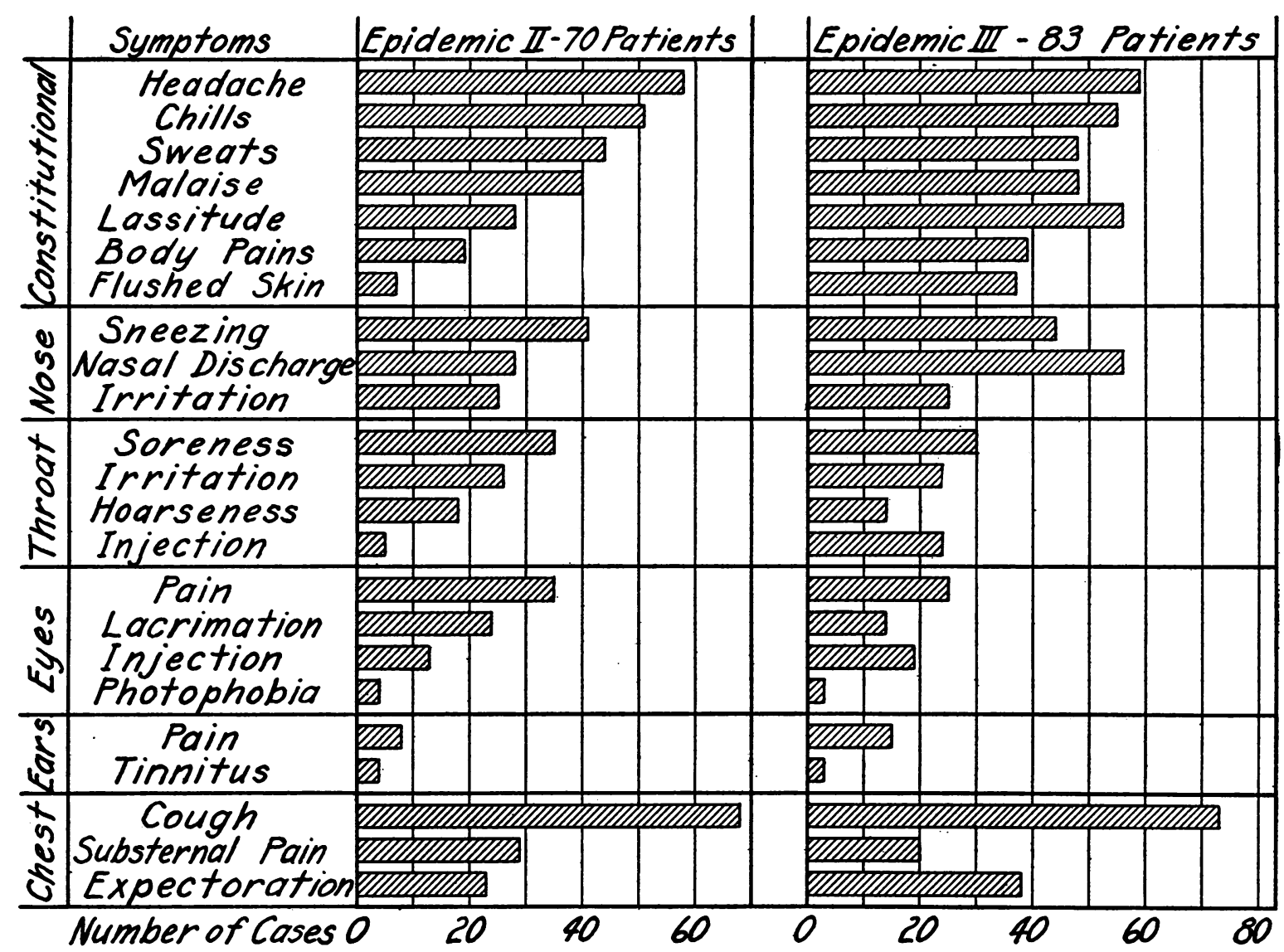

Fig. 1. Frequency of Cinical Symptoms in 153 Cases of Epidemic Influenza

existing colds. As was noted in Epidemic 2, there was an increased prevalence of colds during the same period. The frequency of various symptoms among cases in Epidemic 3 has been summarized in Figure 1 . The similarity of the clinical characteristics of the disease as it occurred in Epidemic 2 and Epidemic 3 is obvious. In both epidemics the disease was relatively mild. The mean duration of symptoms in Epidemic 3 was 4.9 days. No cases of postinfluenzal pneumonia occurred, and both epidemics were characterized by the absence of complications. There were no deaths attributable to either of these epidemics.

Epidemic 4. New York State Homeopathic Hospital. Between March 6 and 15, 1939, 71 inmates of this institution contracted an acute respiratory infection. Doctor Wendall R. Ames of the New York State Department of Health, who made the original epidemiological investigation, reported that a number of the patients had become ill with rhinitis, injected conjunctiva, and generalized symptoms such as malaise, aching, and prostration. It was extremely difficult to obtain accurate histories on these patients because practically all of the cases occurred in a building housing the most mentally deteriorated types of adult male inmates. The temperatures were not high, rarely rising above $102^{\circ} \mathrm{F}$. Never- theless, 3 patients subsequently developed pneumonia, 1 of them dying as a result. The illness was almost entirely limited to what is called the West Group, which contains 700 of the 3,500 inmates of the entire institution. Seventy-one of the 700 patients were affected. A few employees were ill also, and a few cases occurred in other parts of the hospital; but the disease reached epidemic proportions in the West Group only.

Investigation of this epidemic was begun by one of us (E. R. R.) on March 13. Histories of illness identical to those which had been obtained in Epidemics 2 and 3 were given by 6 attendants who had been taken ill while working in the affected wards. No attempt was made to obtain histories from inmates. Study of the temperature records of 66 patients revealed that the extent and duration of fever had been similar to that observed in Epidemic 2. With the exception of the 3 cases of pneumonia, the disease ran a mild and uncomplicated course. The patients affected by pneumonia were among the most aged and debilitated of the group.

Epidemiologically, the disease in Epidemic 3, which occurred in a suburban population, differed from that observed in Epidemics 2 and 4, which were confined to large institutions. In Epidemic 3, based on an average of 1,374 persons under observation in the Yorktown Heights 
area during January, February, and March, the attack rate was 6 per cent, which was considerably lower than the rates observed in the two institutional epidemics. In both institutions the epidemics were explosive in character and had sharp peaks which occurred during periods of 2 or 3 days, while the entire episodes ended within periods of less than 2 weeks. Table III reveals that Epidemic 3 spread over a period of approximately 21/2 months, with a peak during the 15-day interval from February 5 to 18, inclusive. During the month of April 1939 only 2 cases of febrile upper respiratory disease were observed in the Yorktown Heights area. As this was the same incidence that had been observed in April 1938, it was concluded that the epidemic had ended during the latter part of March.

There was no significant geographical distribution of the cases in Epidemic 3. Forty-two occurred as single cases in a family, while the remaining 41 were distributed among 14 families with 2 to 7 cases in each. Distribution by age and sex followed closely the age and sex distribution of the total population under observation, with the exception that no cases were noted in children under 4 years of age. This discrepancy might be due to the fact that the disease was relatively mild, with symptoms largely of a subjective nature and, therefore, not readily recognized in infants and small children.

\section{METHODS}

Throat washings. Sixty-five throat washings were obtained from representative patients in the four epidemics who had clinical symptoms considered to be consistent with the diagnosis of epidemic influenza. Forty-six throat washings were taken from patients whose symptoms were considered not to be consistent with epidemic influenza. The latter group comprised 18 cases of common cold, 9 cases of sporadic grippe, "11 cases of so-called "atypical pneumonia," and 8 cases of pneumococcus pneumonia, all of which occurred between October 1 and December 31, 1938. A few cubic centimeters of either sterile beef infusion broth or equal parts of broth and sterile saline were dropped into the nostrils of each patient, and after this approximately $30 \mathrm{cc}$. of broth or broth-saline were gargled. The throat washings were frozen in solid carbon dioxide within 5 minutes of the time when they were taken, and they were transported to the laboratory in the frozen state. During the intervals between the time that the throat washings were obtained and their inoculation into ferrets they were stored in a low temperature cabinet (13) at $-76^{\circ} \mathrm{C}$. The washings were taken at various intervals after the onset of the disease, and in the case of epidemic influenza, washings on each day from the 1st to the 8 th were studied.

Blood specimens. Two or more blood specimens were taken from each of 146 patients in the four epidemics, as well as from 117 persons who had either no symptoms or noninfluenzal respiratory disease. The latter group comprised 33 persons who had had intimate contact with cases of epidemic influenza, 56 with cases of common cold, 19 with cases of sporadic grippe, 5 with cases of so-called atypical pneumonia, and 4 with cases of pneumococcus pneumonia. The acute-phase blood specimens were taken at various intervals after the onset of the disease, and specimens from the 1st to the 10th day have been studied. Convalescent specimens were taken from the 10th to the 66th day after onset. In the case of Epidemic 4 specimens were taken from each of 20 patients at weekly intervals for 4 weeks. Serum was separated from the clot in the usual way and was stored at $4^{\circ} \mathrm{C}$.

Inoculation of ferrets. Two cubic centimeters of the unfiltered throat washings were routinely inoculated intranasally into a ferret under ether anesthesia. Ferret temperatures were taken twice daily, and any abnormal nasal signs, respiratory symptoms, or decrease in food consumption were noted. Ferrets were considered to show evidence of experimental influenza when their temperature exceeded $103.9^{\circ} \mathrm{F}$. on the $2 \mathrm{nd}$, 3rd, or 4th day after inoculation and when they simultaneously manifested signs of nasal infection, increase in respiratory rate, and a decrease in appetite. Serial passage in ferrets was carried out routinely at an interval of 4 to 5 days. For the purpose of passage $2 \mathrm{cc}$. of a 20 per cent suspension of turbinate plus lung, or of lung alone, were inoculated intranasally into ferrets anesthetized with ether. The suspensions were routinely cultured for the presence of bacteria. When evidence was desired regarding immunity in an inoculated ferret, the animal was allowed to recover from infection and was bled on the 10th to the 12th day after inoculation. Neutralization tests were done in mice with the convalescent ferret serum.

Inoculation of mice. When, by means of serial ferret passage, evidence had been obtained that a virus was present in the throat washings, attempts to adapt the virus to mice were initiated in many instances. For this purpose $0.05 \mathrm{cc}$. of unfiltered 20 per cent suspension of ferret turbinate plus lung, or of lung alone, was given intranasally to each of a group of young Swiss mice anesthetized with ether. Serial passage in mice was continued at an interval of 4 to 5 days, routinely using 0.05 cc. of unfiltered 20 per cent suspension of mouse lung. The suspensions were routinely cultured for the presence of bacteria.

Neutralization tests. The exact details of the technique which has been used for the determination of the neutralizing titer of sera have been described previously (14). The sera were inactivated at $56^{\circ} \mathrm{C}$. for $1 / 2$ hour. Acute and convalescent sera were studied simultaneously against one suspension of the PR8 strain of epidemic influenza virus. Serial fourfold dilutions of serum were made in 0.85 per cent $\mathrm{NaCl}$. These dilutions were tested for their capacity to neutralize a constant amount of virus. In one-third of the tests a $10^{-4}$ dilution, or approximately 300 fifty per cent mortality doses, of virus was used. In the other two-thirds of the tests a $10^{-4}$ dilution, or approximately 3,000 fifty per cent mortality doses, of virus was used. Groups of either three or four Swiss mice were tested with each mixture of serum and virus and observed for a 10-day period. The survivors 
were then killed and their lungs examined for the presence of pulmonary consolidation. The calculation of end points was done by the method of Reed and Muench (15). In all instances the fifty per cent mortality end point was chosen. In the various tables presented below, all serum titers are expressed in terms of the neutralizing capacity against 3,000 fifty per cent mortality doses of virus. In the case of those neutralization tests in which 300 fifty per cent mortality doses were used the recorded titers have been calculated by means of the formula $y=b x^{a}$ (14), on the basis that there is a linear relationship between the quantity of serum and the quantity of influenza virus neutralized. A significant increase in the neutralizing antibody titer of a convalescent serum has been taken to equal an increase in titer of 4 or more times over the acute serum titer.

Tests of antisera. Convalescent ferret sera were obtained 10 to 12 days after inoculation. Rabbit antisera were obtained 10 to 12 days after the intraperitoneal injection of either ferret- or mouse-adapted virus. These antisera were studied in a manner identical to that described above.

Isolation of virus. One hundred and eleven throat washings have been tested for the presence of epidemic influenza virus by serial passage in ferrets. The throat washings were selected from 65 representative cases of epidemic influenza and from 46 cases of various acute noninfluenzal infections of the respiratory tract. The selection of throat washings was made entirely on a clinical basis without regard for the demonstration of a rise in antibodies against epidemic influenza virus in the convalescent sera of the patients from whom they were obtained. Three hundred and eighty-eight ferrets were used in this study, and each throat washing from both groups of cases was passed an average of 3.5 times in ferrets.

\section{EXPERIMENTAL}

The results of the serial ferret passage of the throat washings are summarized in Table IV. Twenty-nine of the 65 throat washings from patients with clinical epidemic influenza produced what was considered to be experimental influenza in the ferret. In the case of 14 of these 29 strains of virus, antisera obtained from various of the ferret passage series have contained neutralizing antibodies against the PR8 strain of epidemic influenza virus. In the case of the remaining 15 strains of virus the studies are not yet completed. Despite the fact that serial ferret passage was carried out with the throat washings from 65 cases of epidemic influenza, only 45 per cent were capable of producing experimental ferret influenza. Evidence will be presented subsequently which indicates that at least 93 per cent of the patients from whom these 65 throat washings were taken
TABLE IV

Results of serial ferret passage of throat washings from persons with various acute infections of the respiratory tract

\begin{tabular}{|c|c|c|c|c|}
\hline Clinical diagnosis & $\begin{array}{c}\text { Num- } \\
\text { ber } \\
\text { of } \\
\text { throat } \\
\text { wash- } \\
\text { ings }\end{array}$ & $\begin{array}{c}\text { Number } \\
\text { pro- } \\
\text { ducing } \\
\text { ferret } \\
\text { influ- } \\
\text { enza- }\end{array}$ & $\begin{array}{c}\text { Num- } \\
\text { ber of } \\
\text { strains } \\
\text { of } \\
\text { virus } \\
\text { proven }\end{array}$ & $\begin{array}{c}\text { Per cent } \\
\text { pro- } \\
\text { ducing } \\
\text { ferret } \\
\text { influ- } \\
\text { enza }\end{array}$ \\
\hline $\begin{array}{l}\text { Epidemic influenza : } \\
\text { Epidemic } 1 \ldots \ldots \ldots \ldots \ldots \\
\text { Epidemic } 2 \ldots \ldots \ldots \ldots \ldots \\
\text { Epidemic } 3 \ldots \ldots \ldots \ldots \ldots \\
\text { Epidemic } 4 \ldots \ldots \ldots \ldots \ldots\end{array}$ & $\begin{array}{r}6 \\
18 \\
26 \\
\frac{15}{65}\end{array}$ & $\begin{array}{r}4 \\
9 \\
11 \\
5 \\
29\end{array}$ & $\begin{array}{r}1 \\
3 \\
8 \\
2 \\
14\end{array}$ & $\begin{array}{l}66 \\
50 \\
42 \\
33 \\
45\end{array}$ \\
\hline 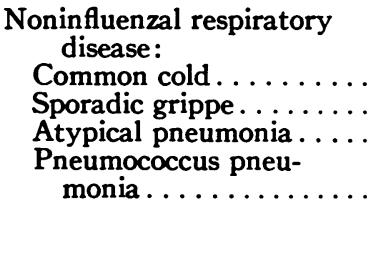 & $\begin{array}{r}18 \\
9 \\
11 \\
8 \\
46\end{array}$ & $\begin{array}{l}0 \\
1 \\
0 \\
0 \\
1\end{array}$ & $\begin{array}{l}0 \\
1 \\
0 \\
0 \\
\frac{1}{1}\end{array}$ & $\begin{array}{r}0 \\
11 \\
0 \\
0 \\
2\end{array}$ \\
\hline
\end{tabular}

actually did have epidemic influenza. This relatively low recovery rate of virus is in contrast to the high recovery rates which have previously been published $(9,12)$ for epidemics which occurred in 1936 to 1937.

From the 46 throat washings obtained from persons with noninfluenzal acute respiratory diseases, only one strain of epidemic influenza virus was isolated.

This strain was obtained from a throat washing taken on November 11, 1938, from a technician in this laboratory who had symptoms of sporadic grippe. This individual had been working for over 2 months with various animal and tissue culture strains of epidemic influenza virus. Studies of blood specimens from this individual taken on the 1st day of the illness and 20 days later failed to show any evidence of an increase in titer of neutralizing antibodies against the PR8 strain of epidemic influenza virus.

It seems reasonable to suggest that the isolation of virus from this individual may represent an additional instance of a possible temporary carrier state unrelated to the clinical symptoms. One somewhat similar instance has been previously reported by Francis, Magill, Rickard, and Beck (9). In the case of the other 45 throat washings in the noninfluenzal group, no evidence was obtained of the presence of influenza virus.

The 65 throat washings from cases of epidemic influenza were taken from the 1 st to the 8 th day 
TABLE V

Results of serial ferret passage of throat washings taken at various intervals after onset of epidemic influenza

\begin{tabular}{c|c|c|c|c}
\hline \hline $\begin{array}{c}\text { Number } \\
\text { of days } \\
\text { after } \\
\text { onset }\end{array}$ & $\begin{array}{c}\text { Number } \\
\text { of } \\
\text { throat } \\
\text { washings }\end{array}$ & $\begin{array}{c}\text { Number } \\
\text { producing } \\
\text { ferret } \\
\text { influenza }\end{array}$ & $\begin{array}{c}\text { Number of } \\
\text { strains } \\
\text { of virus } \\
\text { proven }\end{array}$ & $\begin{array}{c}\text { Per cent } \\
\text { producing } \\
\text { ferret } \\
\text { influenza }\end{array}$ \\
\hline 1 & 14 & 6 & 5 & 42 \\
2 & 19 & 11 & 3 & 58 \\
3 & 14 & 7 & 4 & 50 \\
4 & 7 & 2 & 1 & 28 \\
5 & 2 & 1 & 1 & 50 \\
6 & 5 & 1 & & 20 \\
7 & 2 & 1 & & 50 \\
8 & 2 & 0 & & 0 \\
\hline
\end{tabular}

after onset. The results of the serial ferret passage of these various throat washings in relation to the time when they were obtained are shown in Table $\mathrm{V}$.

It will be noted that experimental ferret influenza was produced by throat washings which were taken on each of the days from the 1 st to the 7 th after onset, and that the fact that the ferret disease was actually due to influenza virus infection had been proved in the case of throat washings taken on each of the days from the 1st to the 5th after onset of the disease. It appears also that there was no significant difference in the incidence with which experimental ferret influenza was produced by throat washings taken from the 1st to the 7th day after onset. It has previously been reported (11) that virus was isolated from one patient on the 1st, 2nd, 4th, and possibly the 7th day after onset.

Serial ferret passage, although laborious and time consuming, has been considered necessary with the throat washings obtained from the 1939 epidemics of influenza because of the frequency with which the first ferret inoculated failed to show an interpretable reaction. Even when the ferret reaction was definite enough to indicate infection by epidemic influenza virus, it was considerably less striking than has been the case in previous years $(1,12)$, and a diphasic fever was typically absent. Instead there was usually a single temperature peak which occurred either upon the 2nd, 3rd, or 4th day after inoculation, and the highest temperature seldom exceeded $104.5^{\circ} \mathrm{F}$.

In the case of the 29 throat washings which produced experimental influenza in the ferret, 6 produced no significant response in the first ferret inoculated; 5 of these produced a suggestive response in the second-passage ferret; but one did not produce recognizable disease in the ferret until the third passage. Even in the case of the 23 throat washings which produced some evidence of experimental influenza in the first ferret inoculated, the response in this animal was minimal and was interpreted with difficulty until additional ferret passages had been completed.

To illustrate the difficulties encountered in the study of throat washings obtained from epidemics in 1939, an analysis has been made of the results of relatively prolonged serial ferret passage with 21 of the 29 strains isolated this year. The results obtained in a total of 150 ferrets have been analyzed. An average of 7.1 passages in ferrets was made with each of these 21 strains. These results are presented in Table VI. It will be noted that, although evidence indicating the presence of epidemic influenza virus was obtained in the case of each of the 21 throat washings, only 15 of the first-passage ferrets showed significant responses. Eighty-five ferrets received unfiltered 20 per cent suspensions of ferret turbinate plus lung in the course of the serial passages, but only 53 gave evidence of the presence of epidemic influenza virus. In the case of 44 ferrets which received unfiltered 20 per cent suspension of ferret lung, only 24 developed fever and symptoms indicative of epidemic influenza virus infection. These results are presented as evidence that the ferret response has been inconstant with strains isolated in 1939 . In 38 per cent of 150 ferrets

\section{TABLE VI}

Results of serial ferret passage of 21 throat washings known to contain epidemic influenza virus

\begin{tabular}{|c|c|c|c|c|}
\hline Inoculum* & $\begin{array}{l}\text { Num- } \\
\text { ber } \\
\text { of } \\
\text { fer- } \\
\text { rets }\end{array}$ & $\begin{array}{l}\text { Num- } \\
\text { ber } \\
\text { with } \\
\text { influ- } \\
\text { enza }\end{array}$ & $\begin{array}{l}\text { Num- } \\
\text { ber } \\
\text { with- } \\
\text { out } \\
\text { influ- } \\
\text { enza }\end{array}$ & $\begin{array}{l}\text { Per } \\
\text { cent } \\
\text { with } \\
\text { influ- } \\
\text { enza }\end{array}$ \\
\hline $\begin{array}{l}\text { Unfiltered throat washings . . . . . } \\
20 \text { per cent suspension ferret turbi- } \\
\text { nate and lung . . . . . . . . . . } \\
20 \text { per cent suspension ferret lung }\end{array}$ & $\begin{array}{l}21 \\
85 \\
44\end{array}$ & $\begin{array}{l}15 \\
53 \\
24\end{array}$ & $\begin{array}{r}6 \\
32 \\
20\end{array}$ & $\begin{array}{l}72 \\
63 \\
55\end{array}$ \\
\hline & 150 & 92 & 58 & 62 \\
\hline
\end{tabular}

* 2 cc. 
which received 21 strains, the reaction produced was not sufficiently definite to permit of a diagnosis of experimental ferret influenza. These results indicate also that even when consolidation was not present in the ferret lung, evidence for the presence of virus in the lung was obtained with almost the same frequency as when the turbinates also were tested. The fact that ferrets which did not show a significant response to the 1939 strains actually were infected by these strains was shown by neutralization tests on serum taken from them 10 to 12 days after inoculation.

Additional evidence for the relatively low ferret virulence of the various strains of virus which have been isolated in 1939 is given by the infrequency with which pulmonary consolidation was produced. Three of the most ferret-virulent strains were selected for continuous passage. Strain 149 was passed through 23 ferrets and produced small areas of consolidation at the 12 th, 20th, 21st, and 22nd passages but not in other passages. Strain 188 was passed through 25 ferrets and produced small areas of consolidation at the 9th, 17th, and 22nd passages but not in other passages. Strain 399 was passed through 16 ferrets and produced small areas of pulmonary consolidation in the 7 th, 8 th, 12 th, 13 th, and 15 th passage ferrets but not in any other ferrets.

Adaptation to mice. Nineteen attempts have been made to establish in mice 15 of the 29 strains which have been isolated in 1939 . Each of these attempts was made after serial ferret passage of the virus. Ten of the attempts have been unsuccessful although serial passage in mice was continued. In nine instances the various virus strains have been successfully established in mice. The results of the serial mouse passages are shown in Table VII. It will be noted that in the ten unsuccessful attempts an average of only 2 ferret passages had been carried out prior to the inoculalation of mice. An average of 6 serial passages in mice was made, and in no instance did the virus produce significant lesions in the mouse. In the case of the nine successful adaptation series an average of 4 serial ferret passages was made before the inoculation of mice, and an average of 4 serial mouse passages was necessary before significant lung lesions were produced. As has previously been found by other workers $(2,16)$, mouse virulence gradually increased after adapta-
TABLE VII

Results of serial mouse passage of 15 strains of epidemic influenza following serial ferret passage

\begin{tabular}{|c|c|c|c|c|}
\hline \multirow{2}{*}{$\begin{array}{c}\text { Strain } \\
\text { number }\end{array}$} & \multicolumn{2}{|c|}{$\begin{array}{l}\text { Unsuccessful attempts to } \\
\text { adapt virus to mice }\end{array}$} & \multicolumn{2}{|c|}{$\begin{array}{l}\text { Successful attempts to } \\
\text { adapt virus to mice }\end{array}$} \\
\hline & $\begin{array}{c}\text { Number of } \\
\text { ferret } \\
\text { passages }\end{array}$ & $\begin{array}{c}\text { Number of } \\
\text { mouse } \\
\text { passages }\end{array}$ & $\begin{array}{c}\text { Number of } \\
\text { ferret } \\
\text { passages }\end{array}$ & $\begin{array}{c}\text { Number of } \\
\text { mouse } \\
\text { passages }\end{array}$ \\
\hline $\begin{array}{l}134 \\
135 \\
149 \\
188 \\
206 \\
208 \\
210 \\
233 \\
236 \\
237 \\
241 \\
273 \\
390 \\
399 \\
400 \\
237 \\
237\end{array}$ & $\begin{array}{l}3 \\
3 \\
1 \\
3\end{array}$ & $\begin{array}{r}3 \\
\\
5 \\
8 \\
10 \\
\\
10 \\
10 \\
8 \\
2\end{array}$ & $\begin{array}{r}5 \\
4 \\
2 \\
2 \\
4 \\
10\end{array}$ & $\begin{array}{l}4 \\
8 \\
4 \\
5 \\
4 \\
3\end{array}$ \\
\hline Mean & 2 & 6 & 4 & 4 \\
\hline
\end{tabular}

tion. However, in most instances, the 1939 viruses have remained of relatively low virulence for mice with a fifty per cent mortality end point of only $10^{-3}$ or $10^{-4}$. In only two instances have the viruses been sufficiently virulent to permit of dilutions to $10^{-5}$ and still produce fatal infections in mice.

Tissue culture. Eight separate attempts were made to cultivate 4 strains of the 1939 viruses in chick-embryo-Tyrode tissue culture medium (17). Each of these strains had been well established in mice before tissue culture passage was instituted. In only three of the eight series did the strains remain active for more than 2 or 3 passages.

Antigenic analysis. Strains 149 and 188, which were obtained from Epidemics 1 and 2 respectively, were selected for intensive antigenic study. Antisera against these strains and the PR8 and W.S. strains were prepared in both ferrets and rabbits. These sera were tested for their capacity to neutralize the homologous and the heterologous viruses. Both of the 1939 strains which have been carefully studied appeared to be closely related antigenically, although they did not seem to be absolutely identical. By means of rabbit antiserum neutralization tests, both strains were quite different from either the PR8 or the W.S. strain. However, when homologous convalescent ferret 
TABLE VIII

Results of neutralization tests with epidemic influenza virus on two blood specimens from each of 60 patients with epidemic influenza

(Throat washings from these patients were passed serially in ferrets)

\begin{tabular}{|c|c|c|c|c|c|c|c|c|}
\hline \multirow[b]{2}{*}{ Epidemic } & \multirow{2}{*}{$\begin{array}{c}\text { Num- } \\
\text { ber } \\
\text { of } \\
\text { cases }\end{array}$} & \multicolumn{2}{|c|}{$\begin{array}{l}\text { Acute- } \\
\text { phase } \\
\text { blood }\end{array}$} & \multicolumn{2}{|c|}{$\begin{array}{c}\text { Convalescent- } \\
\text { phase } \\
\text { blood }\end{array}$} & \multicolumn{3}{|c|}{ Increase in titer } \\
\hline & & $\begin{array}{c}\text { Day } \\
\text { mean }\end{array}$ & $\begin{array}{l}\text { Titer } \\
\text { mean }\end{array}$ & $\begin{array}{c}\text { Day } \\
\text { mean }\end{array}$ & $\begin{array}{l}\text { Titer } \\
\text { mean }\end{array}$ & $\begin{array}{c}\text { Num- } \\
\text { ber } \\
\text { of } \\
\text { cases } \\
\text { with } \\
\text { in- } \\
\text { crease }\end{array}$ & $\begin{array}{c}\text { Mean } \\
\text { in- } \\
\text { crease } \\
\text { in } \\
\text { titer }\end{array}$ & $\begin{array}{c}\text { Per } \\
\text { cent } \\
\text { of } \\
\text { cases } \\
\text { with } \\
\text { in- } \\
\text { crease }\end{array}$ \\
\hline $\begin{array}{l}1 \\
2 \\
3 \\
4\end{array}$ & $\begin{array}{r}6 \\
24 \\
16 \\
14\end{array}$ & $\begin{array}{l}2 \\
3 \\
1 \\
4\end{array}$ & $\begin{array}{l}1: 9 \\
1: 14 \\
1: 14 \\
1: 69\end{array}$ & $\begin{array}{l}60 \\
27 \\
27 \\
26\end{array}$ & $\begin{array}{l}1: 61 \\
1: 130 \\
1: 194 \\
1: 424\end{array}$ & $\begin{array}{r}6 \\
23 \\
15 \\
12\end{array}$ & \begin{tabular}{|l}
$25 x$ \\
$18 x$ \\
$38 x$ \\
$25 x$
\end{tabular} & $\begin{array}{r}100 \\
96 \\
94 \\
86\end{array}$ \\
\hline $\begin{array}{l}\text { Cases } \\
\text { yielding } \\
\text { virus }\end{array}$ & 60 & 3 & $1: 26$ & 30 & $1: 209$ & 56 & $26 x$ & 100 \\
\hline
\end{tabular}

$x$ represents the arithmetical increase in the titer of the convalescent serum as compared with the titer of the acute serum.

sera were used, the 1939 strains seemed less distantly related to PR8 than was the case with rabbit antisera, but remained very different from W.S. Antisera against both strains, 149 and 188, failed to neutralize significant amounts of the swine virus.

Neutralization studies. In the group of $65 \mathrm{pa}-$ tients with clinical epidemic influenza, acute and convalescent blood specimens have been tested for their capacity to neutralize the PR8 strain of epidemic influenza virus in 60 cases. The combined results of these tests are shown in Table VIII. The mean time after onset at which the acutephase blood specimens were obtained was 3 days. The earliest specimen was taken on the 1st day and the latest on the 8th day. Ten of the socalled acute-phase blood specimens were actually preinfection specimens which were obtained 9 months before infection. All of these 10 sera came from patients in Epidemic 3. The mean neutralizing antibody titer of the 60 acute-phase sera was $1: 26$. The lowest titer was zero and the highest $1: 360$. The convalescent blood sera were obtained, on the average, 30 days after the onset of the disease. The shortest interval after onset was 22 days and the longest 66 . The mean neutralizing antibody titer of the 60 convalescent sera was $1: 209$. The lowest was $1: 6$, and the highest $1: 1444$. The average increase in titer of the convalescent serum, as compared with the acute serum taken from the same patient, was 26 times. The lowest increase in titer was 4 times; the highest 160 times. Fifty-six of the 60 patients whose acute and convalescent sera were studied showed an increase in neutralizing titer of 4 times or more during convalescence. This represents 93 per cent of the cases studied. In Table VIII the results of neutralization tests on the acute and convalescent blood specimens from 27 of the 29 patients whose throat washings yielded influenza virus are shown separately. In the 2 remaining cases comparative neutralization tests were not done. The similarity between the results in the group which yielded virus and the total group is quite obvious.

In Epidemic 4, 20 cases were selected for weekly bleedings. The neutralization titer of each of these 80 blood specimens has been determined, and the results are shown in Figure 2. The day on which the blood specimens were taken after the clinical onset of the disease has been plotted against the logarithm of the dilution of serum which was capable of neutralizing 3,000 fifty per cent mortality doses of virus. The incremental rise in titer from 4 times to 256 times is graphically shown on the same scale.

The general trend of the rise in neutralizing antibodies following clinical epidemic influenza was similar in almost all of the 20 cases in this series. It appeared that the maximum neutralizing titer in these cases was achieved between the 10 th and 14th day after onset. It is to be noted that approximately 50 per cent of the increase in antibody titer had been accomplished by the 7th or 8th day after onset. This fact is of considerable significance in interpreting the neutralizing antibody titer of sera taken late in the acute phase of the disease. As an example, it is possible that when a comparison is made between an acutephase serum taken on the 7 th day of the disease and a convalescent serum taken on the 20th day of the disease, an increase in neutralizing antibody titer of less than 4 times may be observed. Under these circumstances and if only an increase in titer of 4 times or more is considered to be significant, it will be concluded that no rise in neutralizing antibodies has taken place. 


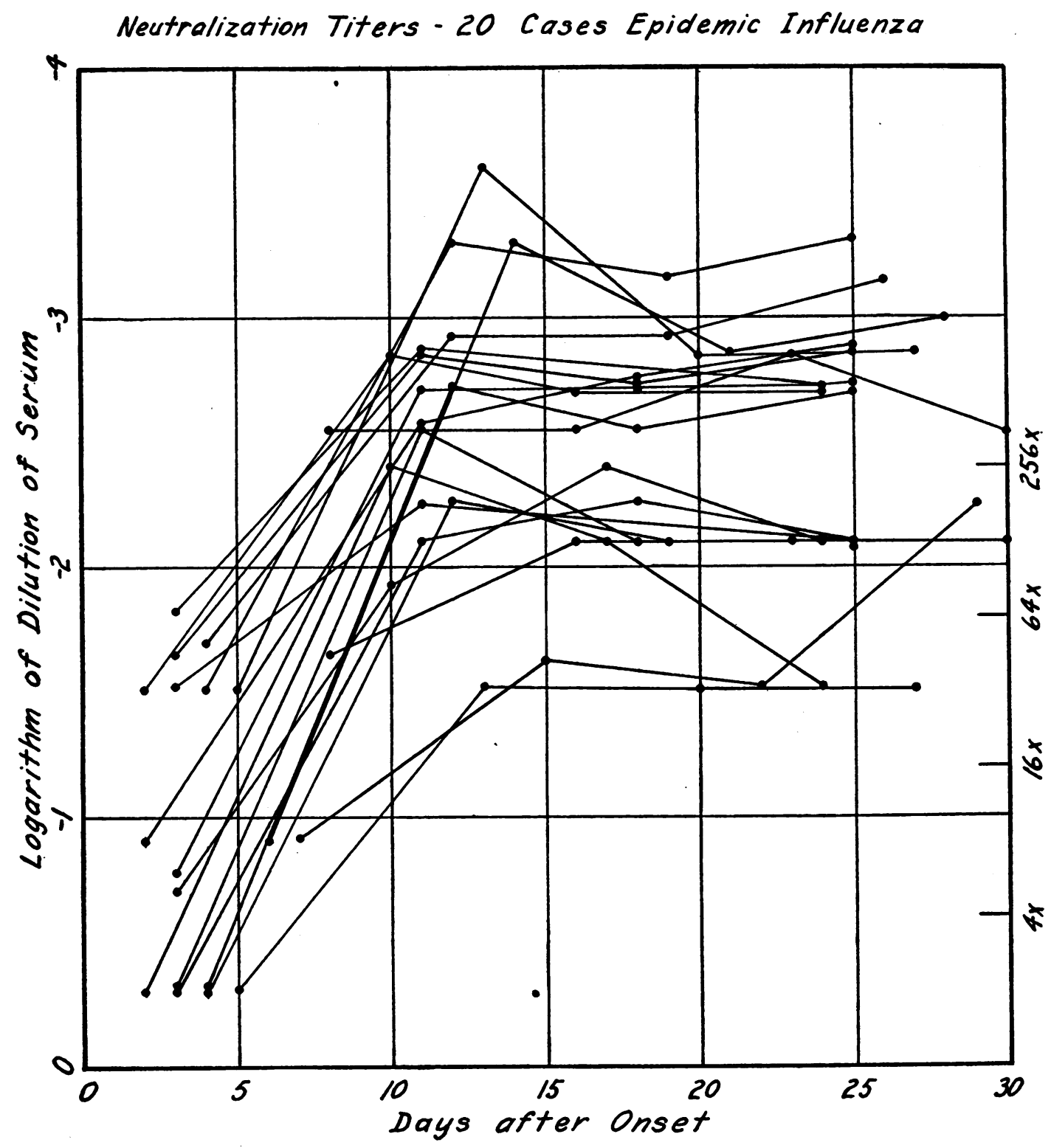

Fig. 2. Neutralizing Antibody Titers At Various Periods After the Onset in 20 Cases of EPtDemic Influenza

Acute and convalescent blood sera have been studied from a total of 146 cases clinically diagnosed as epidemic influenza during 1939 . These include the 60 cases already presented in Table VIII. The results of comparative neutralization tests on the 2 sera from each of these cases are presented in Table IX. The results of complement fixation tests on these sera will be reported separately by Eaton and Rickard (18). One hundred and fifteen, or 79 per cent, of the 146 cases showed an increase in neutralizing antibody titer of 4 times or more during convalescence. Thirtyone cases failed to show a significant increase in neutralizing antibody titer during convalescence, but it should be pointed out that from the 22 patients in Epidemic 4 who failed to show an increase during convalescence the acute-phase blood was taken, on the average, 8 days after the onset of the disease. In the case of the 8 patients in Epidemic 3 who failed to show a significant increase in neutralizing antibodies during convalescence, it may be of significance that the 
TABLE IX

Results of comparative neutralization tests with epidemic influenza virus on two blood specimens from each of 146 patients with epidemic influenza

\begin{tabular}{c|r|c|c|c|c|c}
\hline \hline & & $\begin{array}{c}\text { Acute- } \\
\text { phase } \\
\text { blood } \\
\text { demic }\end{array}$ & $\begin{array}{c}\text { Num- } \\
\text { ber } \\
\text { of } \\
\text { cases }\end{array}$ & $\begin{array}{c}\text { Conva- } \\
\text { lescent- } \\
\text { phase } \\
\text { blood }\end{array}$ & \multicolumn{3}{|c|}{\begin{tabular}{c} 
Increase in titer \\
\cline { 3 - 7 }
\end{tabular}} & $\begin{array}{c}\text { Mean } \\
\text { titer }\end{array}$ & $\begin{array}{c}\text { Mean } \\
\text { titer }\end{array}$ & $\begin{array}{c}\text { Number } \\
\text { of } \\
\text { cases } \\
\text { with } \\
\text { increase }\end{array}$ & $\begin{array}{c}\text { Increase } \\
\text { in mean } \\
\text { titer }\end{array}$ & $\begin{array}{c}\text { Per cent } \\
\text { of } \\
\text { cases } \\
\text { with } \\
\text { increase }\end{array}$ \\
\hline 1 & 6 & $1: 9$ & $1: 61$ & 6 & $25 \times$ & 100 \\
2 & 24 & $1: 14$ & $1: 130$ & 23 & $18 \times$ & 96 \\
3 & 49 & $1: 13$ & $1: 193$ & 41 & $26 \times$ & 84 \\
4 & 67 & $1: 41^{*}$ & $1: 262$ & 45 & $26 \times$ & 67 \\
\hline & 146 & $1: 22$ & $1: 209$ & 115 & $21 \times$ & 79 \\
\hline
\end{tabular}

$x$ represents the arithmetical increase in the titer of the convalescent serum as compared with the titer of the acute serum.

* Twenty-five of the 67 acute-phase blood specimens have been excluded in the calculation of this titer since they were collected on the 8th day after onset or later.

convalescent sera were compared with preinfection sera which were obtained from these persons, on the average, 9 months before the onset of the disease. The results of these neutralization tests are presented comprehensively in Figure 3 , in which the relative accumulated frequencies of the different titer groups have been plotted against the observed titers. The two lines which have been drawn between the respective points for the acute and convalescent sera illustrate graphically

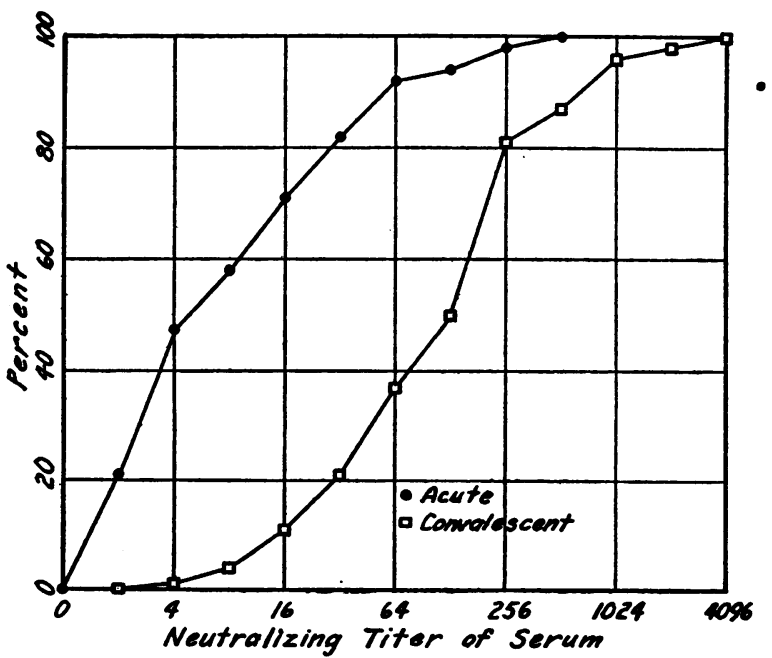

Fig. 3. Relative Accumulated Frequencies of Neutralizing Antibody Titers of Acute and Convalescent Sera from 146 Cases of Epidemic Influenza

Twenty-five acute sera taken on the 8th day after onset or later have been excluded. the distribution of neutralizing antibody titers in these sera. The area between the lines gives a graphic indication of the increase in titer which occurred during convalescence.

Contacts. Each of 33 persons who had contact with cases of epidemic influenza in the course of the four epidemics contributed two blood specimens, one during or before the epidemic and one after. Neutralization tests have been made with these sera, the results of which are presented in Table X. Complement fixation studies on these

TABLE $X$

Results of comparative neutralization tests with epidemic influensa virus on two blood specimens from each of 33 persons who had contact with cases of epidemic influenza

\begin{tabular}{|c|c|c|c|c|c|c|}
\hline \multirow[b]{2}{*}{ Group } & \multirow[b]{2}{*}{$\begin{array}{l}\text { Num- } \\
\text { ber } \\
\text { of } \\
\text { cases }\end{array}$} & $\begin{array}{l}\text { Intra- } \\
\text { epi- } \\
\text { demic } \\
\text { blood }\end{array}$ & $\begin{array}{l}\text { Post- } \\
\text { epi- } \\
\text { demic } \\
\text { blood }\end{array}$ & \multicolumn{3}{|c|}{ Increase in titer } \\
\hline & & $\begin{array}{l}\text { blood } \\
\begin{array}{c}\text { Mean } \\
\text { titer }\end{array}\end{array}$ & $\begin{array}{c}\text { Mean } \\
\text { titer }\end{array}$ & $\begin{array}{l}\text { Num- } \\
\text { ber } \\
\text { of } \\
\text { cases } \\
\text { with } \\
\text { in- } \\
\text { crease }\end{array}$ & $\begin{array}{l}\text { In- } \\
\text { crease } \\
\text { in } \\
\text { titer } \\
\text { mean }\end{array}$ & $\begin{array}{l}\text { Per } \\
\text { cent } \\
\text { of } \\
\text { cases } \\
\text { with } \\
\text { in- } \\
\text { crease }\end{array}$ \\
\hline $\begin{array}{l}\text { Upper respira- } \\
\text { tory illness... } \\
\text { No illness...... }\end{array}$ & $\begin{array}{r}8 \\
25\end{array}$ & $\begin{array}{l}1: 17 \\
1: 26\end{array}$ & $\begin{array}{l}1: 125 \\
1: 78\end{array}$ & $\begin{array}{l}8 \\
7\end{array}$ & $\begin{array}{r}8 x \\
11 x\end{array}$ & $\begin{array}{r}100 \\
28\end{array}$ \\
\hline & 33 & $1: 23$ & $1: 81$ & 15 & $10 x$ & 45 \\
\hline
\end{tabular}

$x$ represents the arithmetical increase in the titer of the convalescent serum as compared with the titer of the acute serum.

sera will be reported separately by Eaton and Rickard (18). Eight persons in the contact group suffered from mild and transient upper respiratory infections after the beginning of the epidemics, but in no instance were the symptoms considered to be similar to those seen in the cases diagnosed as epidemic influenza. Each of these 8 patients, however, showed a significant increase in neutralizing antibody titer in the second blood specimen. Twenty-five of the contact individuals had no history of respiratory illness during or immediately after the epidemic period. Nonetheless, 7 , or 28 per cent, of this group also showed a significant increase in neutralizing antibody titer in the second blood specimen. In the contact group as a whole, 45 per cent of the 33 individuals showed a significant increase in neutralizing antibody titer in the second blood specimen. It seems reasonable to interpret these results as additional evidence for the possibility that subclinical infec- 
tion with the virus of epidemic influenza can lead to an increase in antibodies equally as significant as that encountered in frank clinical cases. A comprehensive analysis of the results of the neutralization tests on the entire contact group is presented in Figure 4, in which the relative ac-

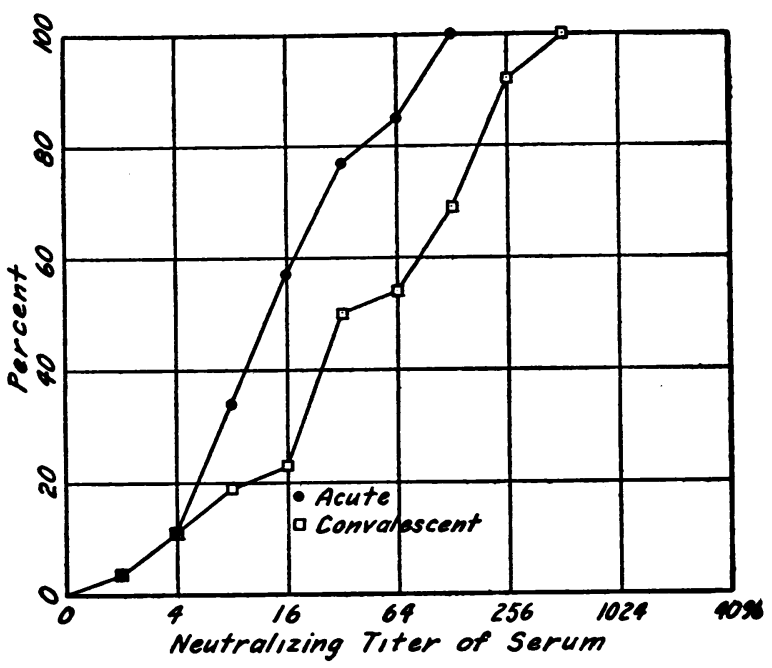

Fig. 4. Relative Accumulated Frequencies of Neutralizing ANTibody Titers of INTRAepidemic and Postepidemic Sera from 33 Influenza Contacts

cumulated frequencies of the various titer groups have been plotted against the observed titers. Although a significant increase in titer occurred in only 15 of the 33 cases, this change was sufficient to displace considerably the line representing the convalescent titers.

Noninfuenzal infections. Eighty-three cases of acute noninfluenzal infections of the respiratory tract have been studied in order to determine the relative levels of neutralizing antibodies against epidemic influenza virus in their acute- and convalescent-phase sera. The results of these comparative neutralization tests are presented in Table XI. Two blood specimens from each of $56 \mathrm{pa-}$ tients with common colds were studied. A significant increase in neutralizing antibody titer was noted in only 1 case, or 2 per cent. This individual was present in the community during Epidemic 3 and could have had contact with cases of epidemic influenza. Two blood specimens from each of 19 patients with sporadic grippe were studied, and in no instance did a significant increase in neutralizing antibody titer occur during
TABLE XI

Results of comparative neutralization tests with epidemic influenza virus on two blood specimens from each of 83 patients with acute noninfluenzal respiratory infections

\begin{tabular}{|c|c|c|c|c|c|}
\hline \multirow{3}{*}{ Clinical diagnosis } & \multirow{3}{*}{$\begin{array}{c}\text { Num- } \\
\text { ber } \\
\text { of } \\
\text { cases }\end{array}$} & \multirow{3}{*}{$\begin{array}{c}\begin{array}{c}\text { Acute- } \\
\text { phase } \\
\text { blood }\end{array} \\
\begin{array}{c}\text { Mean } \\
\text { titer }\end{array}\end{array}$} & \multirow{3}{*}{$\begin{array}{c}\begin{array}{c}\text { Conva- } \\
\text { lescent- } \\
\text { phase } \\
\text { blood }\end{array} \\
\begin{array}{c}\text { Mean } \\
\text { titer }\end{array}\end{array}$} & \multicolumn{2}{|c|}{ Increase in titer } \\
\hline & & & & \multirow{2}{*}{$\begin{array}{l}\text { Num- } \\
\text { ber } \\
\text { of } \\
\text { cases } \\
\text { with } \\
\text { in- } \\
\text { crease }\end{array}$} & \multirow{2}{*}{$\begin{array}{l}\text { Per } \\
\text { cent } \\
\text { of } \\
\text { cases } \\
\text { with } \\
\text { in- } \\
\text { crease }\end{array}$} \\
\hline & & & & & \\
\hline \multirow{5}{*}{$\begin{array}{l}\text { Common cold . . . . . } \\
\text { Sporadic grippe.... } \\
\text { Atypical pneumonia } \\
\text { Pneumococcus } \\
\text { pneumonia . . . . . . }\end{array}$} & 56 & $1: 28$ & $1: 32$ & 1 & 2 \\
\hline & 19 & $1: 35$ & $1: 36$ & $\mathbf{0}$ & 0 \\
\hline & 5 & 1:6 & $1: 6$ & $\mathbf{0}$ & 0 \\
\hline & 4 & $1: 3$ & $1: 4$ & $\mathbf{0}$ & $\mathbf{0}$ \\
\hline & 83 & $1: 27$ & $1: 30$ & 1 & 1 \\
\hline
\end{tabular}

convalescence. Two blood specimens from each of 5 cases with so-called atypical pneumonia and 4 cases of pneumococcus pneumonia were also studied, and none showed a significant increase in neutralizing antibody titer during convalescence. One case among the total of 83 cases showed a rise in antibodies against epidemic influenza virus during convalescence, but it seems likely that, in this single instance at least, the increase in antibody titer could reasonably be explained by the possibility of contact with patients suffering from epidemic influenza. In Figure 5 are shown the results of a comprehensive

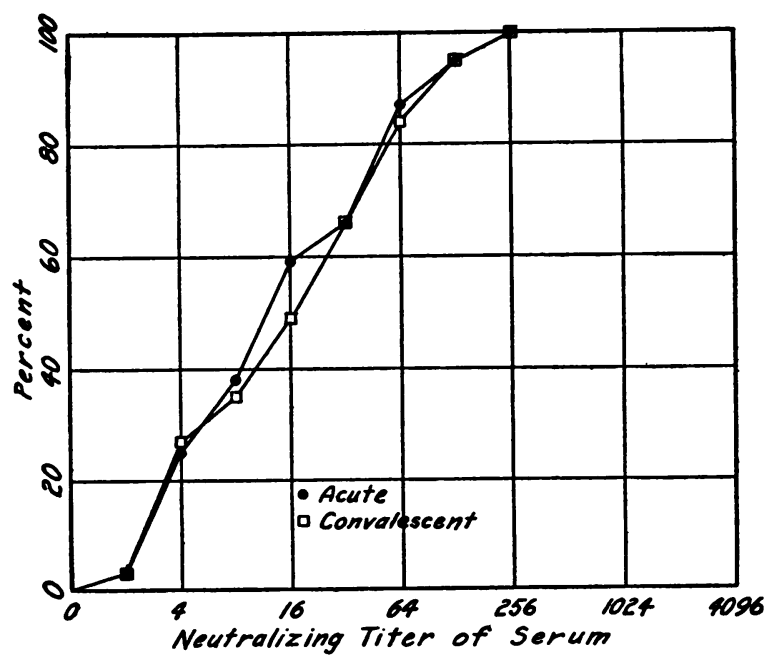

Fig. 5. Reicative Accumulated Frequencies of Neutralizing Antibody Titers of Acute and Convalescent Sera from 83 Cases of Noninfluenzal ReSPIRATORY DISEASE 
analysis of these cases. The relative accumulated frequencies of various titer groups have been plotted against the actual titers. The two lines representing the accumulated results for the acute and convalescent sera respectively have an almost identical position and illustrate graphically the fact that no significant change in titer occurs after these diseases.

In Figure 6 the accumulated frequency data for the acute-phase sera from 121 cases of epidemic influenza and similar data for the acutephase sera from 83 cases of noninfluenzal respiratory disease are compared. These data illustrate

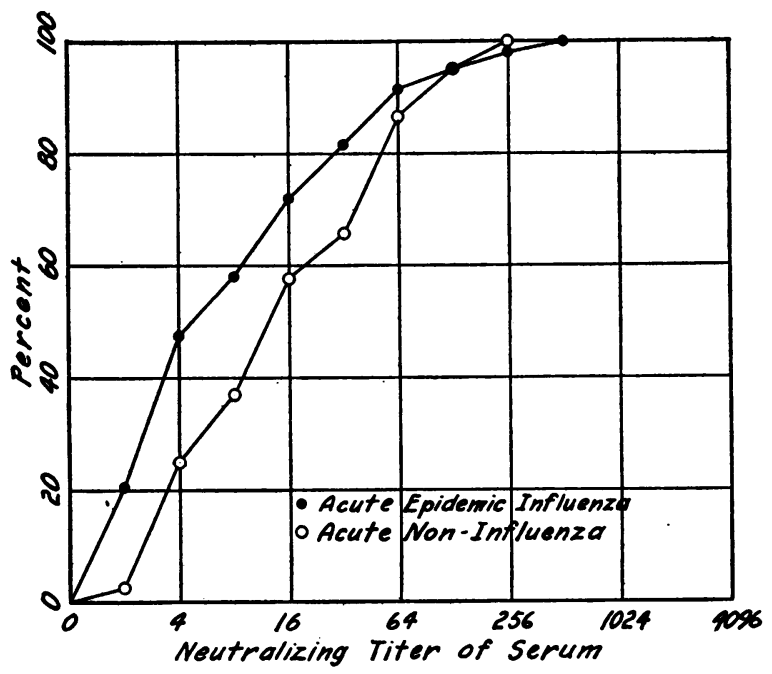

Fig. 6. Relattve Accumulated Frequencies of Neutralizing Antibody Titers of Acute Sera from 121 Cases of Epidemic Influenza and 83 Cases of Noninfluenzal Respiratory Disease

graphically the finding that the acute-phase neutralizing antibody titer was somewhat lower in epidemic influenza than in the noninfluenzal cases, but it does not seem likely that this difference is great enough to be significant.

\section{DISCUSSION}

The reports of previous investigators (1-12) have adequately proved that epidemic influenza is a definite disease entity with an established virus etiology. Unfortunately, there are no known pathognomonic signs or symptoms which permit an accurate clinical diagnosis. Although it has been suggested by Stuart-Harris et al. (12) that in the presence of an epidemic of respiratory dis- ease a certain symptom complex may serve to differentiate influenza from similar but etiologically different diseases, the California epidemic studied by Francis (19) makes this possibility seem unlikely. In the four epidemics which have been studied during 1939 the clinical diagnosis was difficult, although the epidemic nature of the disease was obvious because of the close similarity of the clinical syndromes to those which had been observed in sporadic cases prior to the epidemic. In these latter cases influenza virus was not found in the throat washings, and no increase in neutralizing antibody titer was demonstrable during convalescence. It seems important to emphasize that, although a good correlation has been established in these four epidemics between the clinical diagnosis and the laboratory diagnosis of the disease, the clinical diagnosis was based largely upon the fact that epidemics had occurred and not upon any characteristic symptom complex.

The four epidemics have been characterized by relatively mild clinical disease which was almost uncomplicated. It may be that the mildness of the human disease was paralleled by a relative avirulence of the virus for ferrets, a possibility which has been suggested by Andrewes, Laidlaw, and Smith (3). In these epidemics considerable difficulty was encountered in obtaining evidence that the virus was present in the throat washings, even though serial passage in ferrets was carried out. Frequently, the first ferret inoculated failed to show a reaction which was sufficiently definite to indicate the presence of influenza virus. Even with prolonged serial passage of known strains of virus isolated this year, the responses were inconstant and 38 per cent of the passage ferrets failed to develop significant fever or symptoms. Additional evidence for the relative avirulence of the 1939 strains lies in the fact that they were not easily adapted to mice and were even less readily maintained in tissue culture. Despite this apparent avirulence for susceptible experimental animals, these strains of epidemic influenza virus seem to have been equally as good antigens as the more virulent strains previously isolated. Both experimental antisera against these strains and convalescent serum from patients with the disease possessed neutralizing antibody titers comparable to those produced by the most virulent strains. Not only have the 1939 strains been less virulent 
for experimental animals than those isolated in previous years, but their isolation from the throat washings of serologically proven cases has been less frequent than in previous years. Virus has been obtained from throat washings in only 45 per cent of instances, whereas it was obtained in more than 70 per cent of cases in $1937(11,12)$.

The study of the neutralizing antibody titers of acute and convalescent blood specimens from each of 83 cases of noninfluenzal respiratory infection conclusively demonstrated that no rise in titer against epidemic influenza virus occurred during convalescence from these diseases. In contrast to this, the increase in neutralizing antibody titer noted during convalescence in the large majority of the 146 cases of epidemic influenza was striking. The results of the neutralization tests on the sera obtained at weekly intervals from cases in Epidemic 4 indicate that a rapid increase in neutralizing antibody titer occurred after the onset of the disease.

The contact group presents certain interesting findings. Among the individuals who had contact with cases of epidemic influenza but gave no history of any respiratory infection thereafter, 28 per cent showed an increase in neutralizing antibodies against the virus in their second blood specimens. This seems good evidence that subclinical infection by epidemic influenza virus had occurred. Somewhat similar evidence has been presented by Stuart-Harris et al. (12), and an identical conclusion was reached by Francis et al. (9) on the basis of the antibody titers found in the serum of contacts after an epidemic. The individuals in the contact group who did develop mild upper respiratory infections require special consideration since all of these individuals showed an increase in neutralizing antibodies in their second blood specimens. In none of these cases were the symptoms consistent with a diagnosis of influenza, and in most instances "common cold" seemed the most suitable classification. The precontact levels of neutralizing antibodies in these two groups were almost identical and do not offer any explanation for the fact that, following contact, illnesses occurred in the first group but not in the second.

Two possibilities seem likely: (a) The mild clinical symptoms were unrelated to a subclinical infection by epidemic influenza virus and, therefore, to the increase in neutralizing antibodies; or (b) The virus produced, in these individuals, an unusually mild and aberrant form of the disease which was followed by an increase in antibodies. Both possibilities have some support from the fact that influenza virus previously has been isolated and an antibody rise demonstrated by Francis et al. (11) in (a) a contact who did not develop any symptoms and $(b)$ a contact who had minimal symptoms for 24 hours.

The certain diagnosis of epidemic influenza probably cannot yet be made upon either clinical or epidemiological grounds. Neither can the diagnosis be made solely by serological laboratory tests, since persons who have contact with cases, but themselves remain symptom-free, may develop an increase in antibodies equal to that shown by frank cases. Therefore, a clinical history becomes an essential supplement of the laboratory studies. A certain diagnosis of epidemic influenza still seems to require three types of evidence: (a) clinical history, (b) isolation of virus, and (c) increase in antibody titer against the virus. It seems reasonable to suggest that a definite distinction be made between the disease epidemic influenza and infection by epidemic influenza virus. The former is characterized by a variable symptom-complex, the presence of virus in the nasopharynx, and an increase in antibody titer during convalescence. The latter may be entirely symptomless but nonetheless is followed by an increase in antibody titer.

\section{SUM MARY}

1. Epidemic influenza virus was isolated from cases of influenza in four epidemics during 1939. The virus was not isolated from various cases of acute respiratory disease which occurred prior to the epidemics.

2. The strains of virus isolated produced inconstant reactions in ferrets, and the experimental disease was typically mild. The strains were not easily adapted in mice.

3. Antigenically, these strains were more nearly related to the PR8 strain than to the W.S. strain but were different from both.

4. The neutralizing antibody titer increased rapidly after the 5th day of disease and reached maximum levels between the 10th and 14th days.

5. Contacts developed a significant increase in 
neutralizing antibody titer without manifesting any symptoms.

6. No increase in neutralizing antibody titer occurred during convalescence from four different noninfluenzal respiratory infections.

The authors desire to express their grateful appreciation for the assistance and cooperation received from Dr. Thomas M. Rivers and Dr. Colin M. MacLeod of the Hospital of The Rockefeller Institute for Medical Research; Mr. Frederick C. Helbing, Dr. Anthony J. Flood, and the officers of the New York State Vocational Institution; the practicing physicians and the citizens of Yorktown Heights, New York; Dr. Benjamin Shantz of the Middletown State Homeopathic Hospital; and Dr. Ernest Stebbins, Dr. H. S. Ingraham, Dr. Harry L. Chant, and Dr. Wendell R. Ames of the New York State Department of Health.

\section{BIBLIOGRAPHY}

1. Smith, W., Andrewes, C. H., and Laidlaw, P. P., A virus obtained from influenza patients. Lancet, 1933, 2, 66.

2. Francis, T., Jr., Transmission of influenza by a filtrable virus. Science, 1934, 80, 457.

3. Andrewes, C. H., Laidlaw, P. P., and Smith, W., Influenza: observations on the recovery of virus from man and on the antibody content of human sera. Brit. J. Exp. Path., 1935, 16, 566.

4. Francis, T., Jr., and Magill, T. P., Immunological studies with the virus of influenza. J. Exper. Med., 1935, 62, 505.

5. Burnet, F. M., Influenza virus isolated from an Australian epidemic. Med. J. Australia, 1935, 2, 651.

6. Smorodintsev, A. A., Drobyshevskaya, A. I., and Shishkina, O. I., On the aetiology of the 1936 influenza epidemic in Leningrad. Lancet, 1936, 2, 1383.

7. Pettit, H., Mudd, S., and Pepper, D. S., The Phila- delphia and Alaska strains of influenza virus. J. A. M. A., 1936, 106, 890.

8. Brightman, I. J., and Trask, J. D., Recovery of a filtrable virus from children with influenza; epidemiologic and clinical observations. Am. J. Dis. Child., 1936, 52, 67.

9. Francis, T., Jr., Magill, T. P., Rickard, E. R., and Beck, M. D., Etiological and serological studies in epidemic influenza. Am. J. Pub. Health, 1937, 27, 1141.

10. Hoyle, L., and Fairbrother, R. W., Isolation of the influenza virus and the relation of antibodies to infection and immunity; Manchester influenza epidemic of 1937. Brit. Med. J., 1937, 1, 655.

11. Francis, T., Jr., Magill, T. P., Beck, M. D., and Rickard, E. R., Studies with human influenza virus, during influenza epidemic of 1936-37. J. A. M. A., 1937, 109, 566.

12. Stuart-Harris, C. H., Andrewes, C. H., and Smith, W., A study of epidemic influenza, with special reference to the 1936-37 epidemic. Medical Research Council, Special Report Series No. 228, 1938.

13. Horsfall, F. L., Jr., A low temperature storage cabinet for the preservation of viruses (In press).

14. Horsfall, F. L., Jr., Neutralization of epidemic influenza virus. The linear relationship between the quantity of serum and the quantity of virus neutralized. J. Exper. Med., 1939, 70, 209.

15. Reed, L. J., and Muench, H., A simple method of estimating fifty per cent endpoints. Am. J. Hyg., 1938, 27, 493.

16. Andrewes, C. H., Laidlaw, P. P., and Smith, W., The susceptibility of mice to the viruses of human and swine influenza. Lancet, 1934, 2, 859.

17. Li, C. P., and Rivers, T. M., Cultivation of vaccine virus. J. Exper. Med., 1930, 52, 465.

18. Eaton, M. D., and Rickard, E. R., Complement fixation test in epidemic influenza (In press).

19. Francis, T., Jr., Epidemiological studies in influenza. Am. J. Pub. Health, 1937, 27, 211. 